\title{
The Berkner Island (Antarctica) ice-core drilling project
}

\author{
Robert MULVANEY, ${ }^{1}$ Olivier ALEMANY, ${ }^{2}$ Philippe POSSENTI ${ }^{2}$ \\ ${ }^{1}$ British Antarctic Survey, Natural Environment Research Council, Madingley Road, Cambridge CB3 OET, UK \\ E-mail: r.mulvaney@bas.ac.uk \\ ${ }^{2}$ Laboratoire de Glaciologie et Géophysique de I'Environnement du CNRS (associé à I'Université Joseph Fourier-Grenoble l), \\ 54 rue Molière, BP 96, 38402 Saint-Martin-d'Hères Cedex, France
}

\begin{abstract}
We describe a project to retrieve a $948 \mathrm{~m}$ deep ice core from Berkner Island, Antarctica. Using relatively lightweight logistics and a small team, the drilling operation over three austral summer seasons used electromechanical drilling technology, described in detail, from a covered shallow pit and a fluid-filled borehole. A basal temperature well below pressure-melting point meant that no drilling problems were encountered when approaching the bed and the borehole penetrated through to the base of the ice sheet, and sediment was retrieved from beneath the ice.
\end{abstract}

\section{INTRODUCTION}

Lying to the south of the Weddell Sea, embedded between the Ronne and Filchner Ice Shelves, Berkner Island is the largest Antarctic island (Fig. 1). Roughly kidney-shaped (Fig. 2), it rises to two domes approximately $140 \mathrm{~km}$ apart: Reinwarthhöhe in the north at $720 \mathrm{~m}$ a.s.l., and Thyssenhöhe in the south at 890 ma.s.l., separated by a trough, the McCarthy Inlet. The island has no rock outcrops, and an almost ideal topography for ice-core drilling, with shallow slopes leading to the domes and relatively flat bedrock a little below sea level over much of its base. The first shallow firn cores (to $11 \mathrm{~m}$ depth) were drilled on the north and south domes of the island in 1990 (Wagenbach and others, 1994). Clear seasonal cycles in both the stable isotopes and some chemical species were evident, and it was noted at the time that these two domes appeared to provide ideal sites for longer-term climate records. Deeper cores were recovered in the 1994/95 season, achieving depths of $151 \mathrm{~m}$ on the northern dome (by the British Antarctic Survey (BAS)) and $181 \mathrm{~m}$ on the southern dome (by the Alfred-Wegener-Institut für Polar und Meeresforschung (AWI)) using two shallow electromechanical ice-core drills. Mulvaney and others

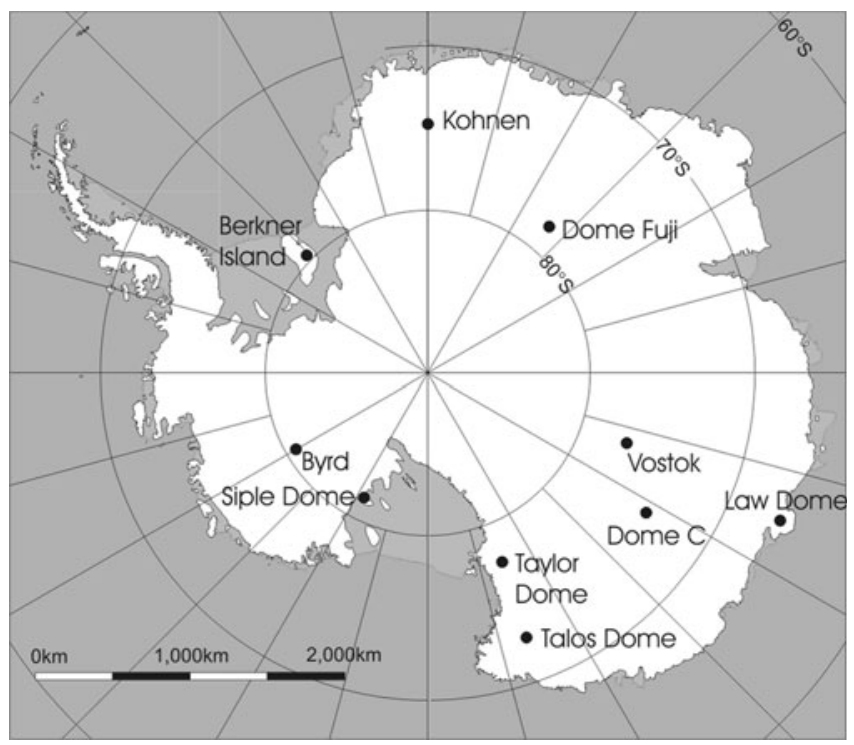

Fig. 1. Location of Berkner Island and other deep ice-core drilling sites in Antarctica. (2002a) describe the drill used by BAS on the northern dome, which was a development of the AWI shallow drill used on the southern dome, itself based on earlier Swiss designs (Rufli and others, 1976; Schwander and Rufli, 1988). Isotopic and chemical records from these ice cores (Mulvaney and others, 2002b) spanned 700 years for the shorter north dome core, while the $181 \mathrm{~m}$ deep core from the southern dome represented approximately 1200 years. Both cores display clear seasonal cycles in electrical conductivity measurements, allowing dating by annual-layer counting and the calculation of accumulation profiles. Stable-isotope measurements (both $\delta^{18} \mathrm{O}$ and $\delta \mathrm{D}$ ), together with the accumulation data, showed multi-decadal variability around a generally stable long-term mean over the past millennium. The $10 \mathrm{~m}$ temperature at the northern dome was measured as $-24.1^{\circ} \mathrm{C}$, while the higher southern dome was measured as $-26.1^{\circ} \mathrm{C}$, with accumulation rates of 210 and $130 \mathrm{~kg} \mathrm{~m}^{-2} \mathrm{a}^{-1}$. Mulvaney and others (2002b) suggested that the southern dome would be an ideal site to gain a climate history of the late stages of the last glacial period and the deglaciation for comparison with the records from the deep Antarctic ice cores, and with other intermediate-depth cores such as Law Dome, Taylor Dome and Siple Dome.

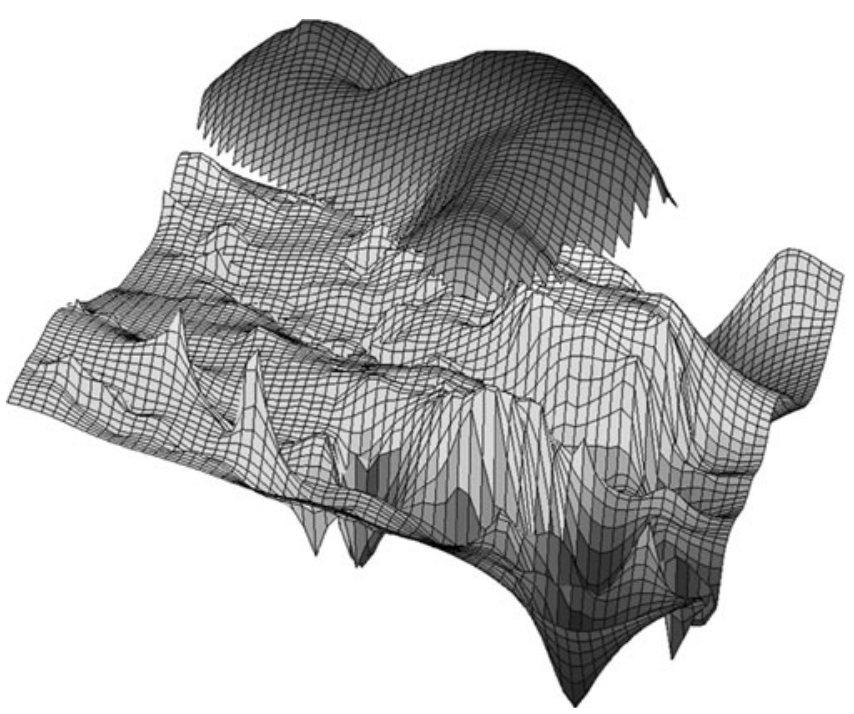

Fig. 2. Surface and bedrock topography of Berkner Island. 

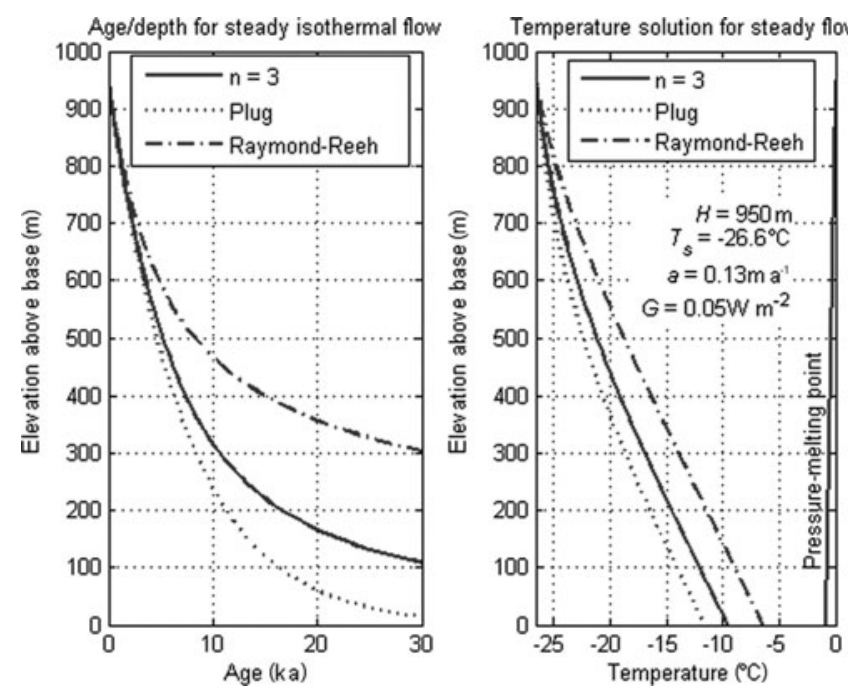

Fig. 3. Model estimates of the depth-age relationship assuming steady isothermal flow (personal communication from R. Hindmarsh, 1999). Three flow-law models are tested, using a column thickness of $950 \mathrm{~m}$, an accumulation rate of $130 \mathrm{~kg} \mathrm{~m}^{-2} \mathrm{a}^{-1}$, a surface mean temperature of $-26.6^{\circ} \mathrm{C}$ and a geothermal heat flux of $50 \mathrm{~mW} \mathrm{~m}^{-1}$

Airborne radio-echo sounding measurements through the ice cap (Sandhäger, 1996) indicated a relatively flat and horizontal bed in the vicinity of the south dome and a thickness of around $950 \mathrm{~m}$. Over-snow radar measurements (Steinhage and Blindow, 1996) showed a near-perfect stratigraphic column (evidenced by the clear internal layers in the radar reflection profiles) through most of the ice thickness, and no evidence of distortion in the layers that might indicate ice flow, or any likely discontinuity in the age-depth profile. From common-midpoint measurements, they gave the thickness as $947 \pm 1 \mathrm{~m}$.

Model estimates of the depth-age relationship (Fig. 3) assuming steady isothermal flow (personal communication from R. Hindmarsh, 1999) predicted that the transition would be at about $250 \mathrm{~m}$ above the bed, with a potential age of more than $30 \mathrm{ka}$ near the bed. This simple model assumed steady isothermal flow based on a column thickness of $950 \mathrm{~m}$, an accumulation rate of $130 \mathrm{~kg} \mathrm{~m}^{-2} \mathrm{a}^{-1}$ and a surface mean temperature of $-26.6^{\circ} \mathrm{C}$. Since no account was taken of lower accumulation in the glacial period, it was reasonable to assume that the ultimate basal age might be considerably older than $30 \mathrm{ka}$. Further, the model predicted a basal temperature of around -10 to $-12{ }^{\circ} \mathrm{C}$, using an estimated geothermal heat flux of $50 \mathrm{~mW} \mathrm{~m}^{-2}$. This basal temperature is well below the pressure-melting point of ice, encouraging for any deep drilling operation: drilling would be unlikely to suffer the problems associated with penetrating near-melting ice.

\section{MOTIVATION FOR THE BERKNER ISLAND DEEP DRILLING PROJECT}

1. Climate change at inland Antarctic sites (Byrd, Vostok) appears to be out-of-phase with Greenland: for example, the Antarctic Cold Reversal (ACR) precedes the Younger Dryas (YD) in Greenland (Sowers and Bender, 1995; Blunier and others, 1997). Recent results from the EPICA (European Project for Ice Coring in Antarctica) Dronning
Table 1. Drill site location and physical characteristics

$\begin{array}{lc}\text { Latitude } & 79^{\circ} 32.9^{\prime} \mathrm{S} \\ \text { Longitude } & 45^{\circ} 40.7^{\prime} \mathrm{W} \\ \text { Altitude } & 890 \mathrm{~m} \text { a.s.l. } \\ \text { Ice thickness } & 947 \pm 1 \mathrm{~m} \\ \text { Accumulation } & 130 \mathrm{~kg} \mathrm{~m}^{-2} \mathrm{a}^{-1} \\ 10 \mathrm{~m} \text { temperature } & -26.5^{\circ} \mathrm{C} \\ \text { Basal temperature } & -11.6^{\circ} \mathrm{C}\end{array}$

Maud Land deep ice core (EPICA Community Members, 2006) show a coupling between all Antarctic warm events and Greenland Dansgaard-Oeschger events during the last glacial period, with the Antarctic warming preceding that of Greenland. However, earlier results reported from Taylor Dome, a near-coastal site in East Antarctica, appeared to cast doubt on this simple pattern, suggesting that at this site the timing of the deglaciation was broadly in phase with Greenland, rather than central Antarctica (Steig and others, 1998). This apparent discontinuity with central Antarctic records poses severe tests on existing models of climate change, which have focused on the role of the Atlantic circulation in transferring heat between the hemispheres (Stocker and Johnsen, 2003) and have generally sought to explain the phasing of Northern/Southern Hemisphere link assuming each polar region responds coherently. Although the detail of the timing of the deglaciation of the Taylor Dome core has been questioned (Mulvaney and others, 2000), at the inception of the project a new climate record of the deglaciation period from a coastal site facing the southern Atlantic Ocean seemed an obvious choice for gaining further insight into the spatial pattern of the phasing.

2. Berkner Island is embedded within the Ronne and Filchner Ice Shelves. To the north of the island lies the Weddell Sea; Berkner ice flows directly into the Weddell on its northern coast. To the east of the island lies a deep bathymetric trench, the Thiel Trough, which reaches depths of $1250 \mathrm{~m}$, while to the west and south further deep troughs reach depths of 750-1400 m. Thus, ocean water is able to flow around the whole of the raised bedrock below Berkner. Melting of the lower surface of the Filchner-Ronne provides a significant outflow of iceshelf water, which is a contributor to the deep Antarctic Bottom Water (AABW) entering the Atlantic Ocean circulation system (Foldvik and others, 1985). While the exact flux of AABW from the Weddell Sea has proven hard to quantify in the context of experimental uncertainties and variability on different timescales, it is universally accepted that this is the major source region for this water mass (e.g. Jacobs, 2004). At the Last Glacial Maximum (LGM), shelf ice is likely to have reached further northwards in the Weddell Sea, probably to the continental-shelf break (e.g. Huybrechts, 2002). The position of the ice-shelf front is likely to have had an impact on the production and outflow of AABW, and with it, perhaps, an influence on the global climate (Broecker, 1998). Knowledge of the evolving climate of this source region for cold AABW since the LGM, and the extent of the ice sheet, and the timing of its withdrawal from the continental-shelf break seems highly relevant to 


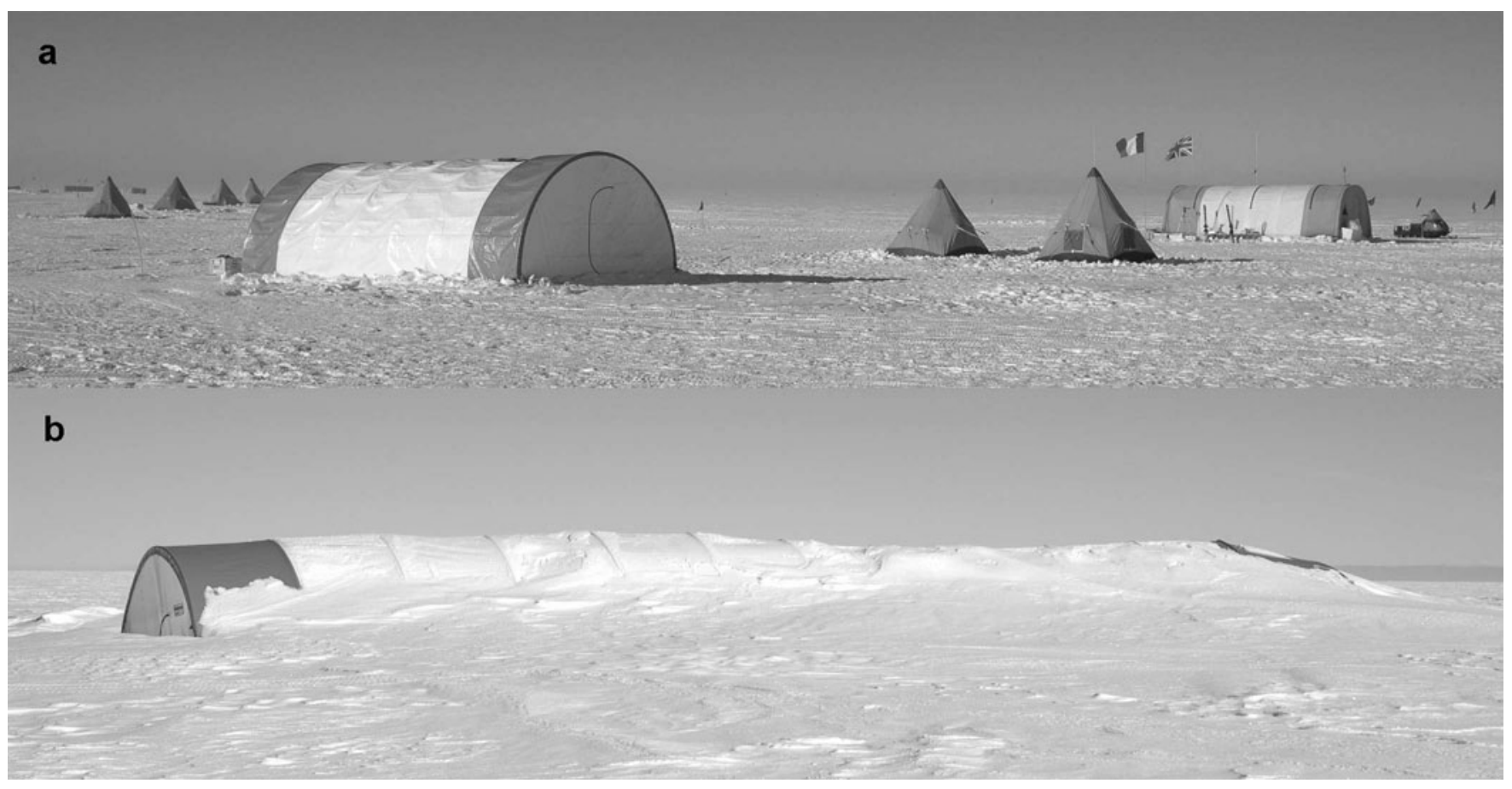

Fig. 4. (a) General view of camp. (b) The drilling tent after two winters of accumulation.

the modelling of the palaeo-ocean circulation system. The Berkner Island ice cap is probably the best site in the Antarctic Peninsula/Weddell Sea region for obtaining a high-resolution climate record for the period from the LGM through to the Holocene.

3. Several models of the extent and thickness of the Antarctic ice sheet through the last glacial cycle indicate that the Antarctic ice sheet extended out into, and filled, the Weddell and Ross Sea embayments. In the Weddell Sea, the ice may have reached the continental-shelf break approximately $450 \mathrm{~km}$ north of Berkner Island, with an ice thickness of up to 2500-3000 m (e.g. Ritz and others, 2001; Huybrechts, 2002). The volume of ice in the Weddell Sea at the LGM could be equivalent to as much as $3-5 \mathrm{~m}$ of sea-level reduction during the late glacial period. The timing of the retreat occurs quite late in some models, with Berkner Island not appearing as an independent ice cap until late in the Holocene at around 4 ka BP (e.g. Huybrechts, 2002). With ice as thick as this, there is the question of the extent of the ice flow across Berkner Island, and whether there was sliding at the base. Gross flow across Berkner Island, and advection of ice from a possible higher-altitude, inland source, clearly poses some difficulties in interpreting any climate record from a deep ice core. However, it was clear that a core from this location would provide some answers to the pertinent glaciological questions of ice thickness and volume in the Weddell Sea at the LGM, the timing of the retreat of the ice and the point at which Berkner Island became an independent ice cap.

\section{PROJECT LOGISTICS}

The location and main physical characteristics of the chosen drilling site are detailed in Table 1 . The primary constraint on the logistics for the drilling project, and a limit to the size and capacity of the drilling system, was the access to the drill site. The UK Antarctic logistic operation (BAS) consists of two ice-strengthened ships for support of the UK Antarctic research stations, four de Havilland ski-equipped Twin Otter aircraft, and one de Havilland Dash-7 four-engined aircraft. The Dash-7 provides a transcontinental link between a gravel runway at Rothera Station on Adelaide Island and South America or the Falkland Islands, together with a link to a blue-ice runway (Sky Blu) in the south of Palmer Land. Field operations remote from the two main Antarctic stations (Rothera on Adelaide Island to the west of the Antarctic Peninsula, and Halley on the Brunt Ice Shelf to the east of the Weddell Sea) are all air-supported by the Twin Otter aircraft, with logistic staging posts at Fossil Bluff (eastern Alexander Island) and Sky Blu. BAS has no capacity for mounting a large over-snow cargo traverse, with the only over-snow cargo vehicles operating to relieve Halley Station, transferring cargo between ships moored alongside the ice shelf and the station. Thus all the drilling and camp infrastructure, fuel, cargo and personnel had to be moved to the drill site by Twin Otter. In practice, most of the heavy cargo was shipped to Halley and transferred to Berkner, a distance of around $900 \mathrm{~km}$. This could be accomplished usually via a direct flight from Halley, with refuelling at the drill site for the return leg. Personnel flew via Dash-7 from the Falkland Islands to Rothera, and then out to the drill site via Twin Otter, a direct distance in excess of $1200 \mathrm{~km}$, with refuelling at Fossil Bluff, Sky Blu and other fuel depots as required by weather or operational constraints. All ice cores were flown to Halley, and loaded into a $-20^{\circ} \mathrm{C}$ refrigerated container on the support ship for return to the UK.

The constraint on transport led to the need for a new drilling system (described later) designed to fit the final Twin Otter leg of the supply chain. It also put limitations on the size of the drilling team, and the type of accommodation. 


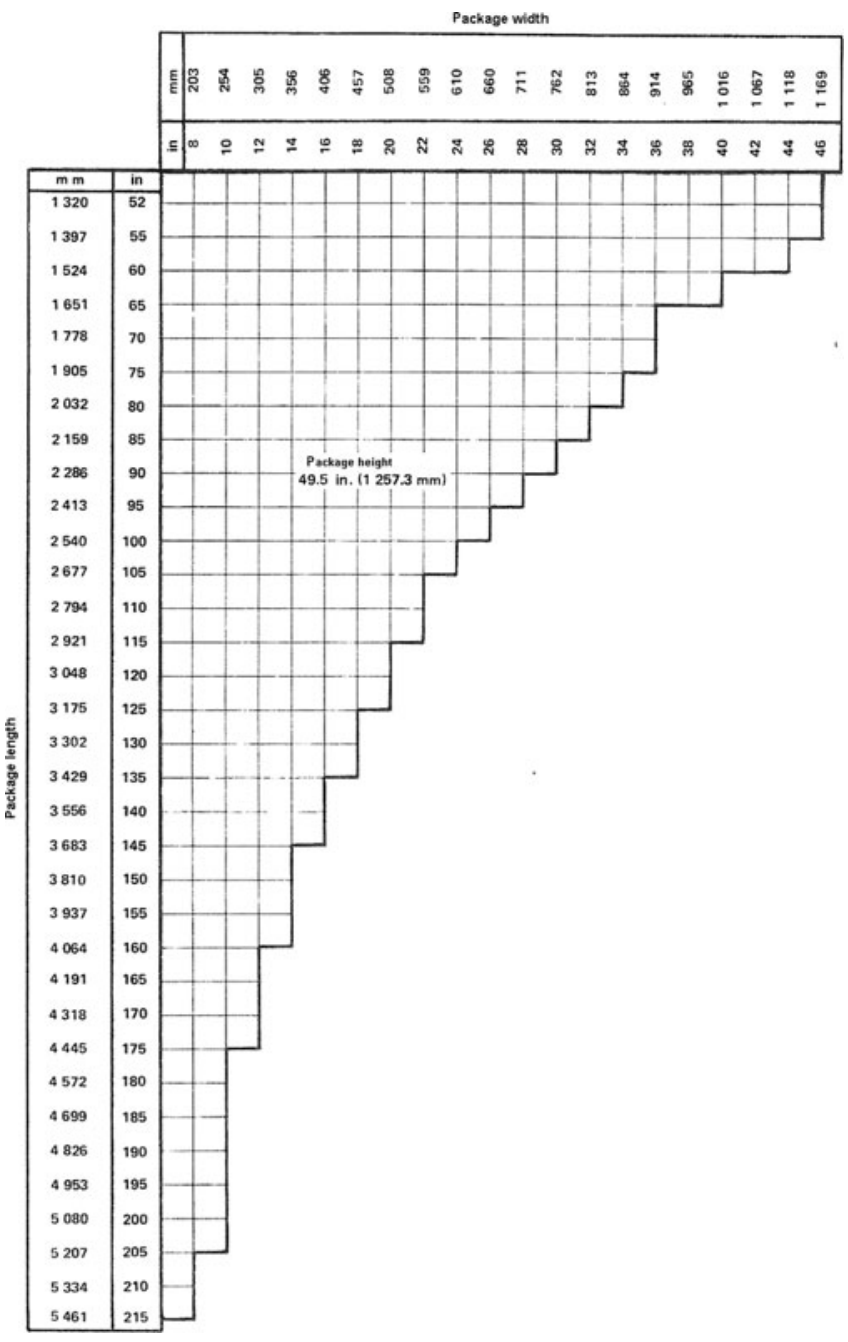

Fig. 5. Loading-width/length restrictions for the de Havilland Series 300 Twin Otter (in $=$ inches).

The field team was limited to a maximum of eight, including drillers, scientists and all support personnel. In fact, the first season (setting up the drilling infrastructure, pilot borehole, reaming and casing) was accomplished by six people in total, the two main drilling seasons (drilling from pilot hole to the base) by just eight people, while the final season (logging the borehole, recovery of the basal sediment and uplift of all infrastructure) required four people at the site. In each season, personnel included a field leader, drillers, scientists and a person primarily responsible for safety and logistics in the field: all drilling and camp-related work, including cooking, was shared between all those in the field. In common with the BAS field procedure, sleeping accommodation was two-person pyramid tents. A larger Weatherhaven Polarhaven shelter $(7.3 \times 3.7 \mathrm{~m})$ was provided for messing and relaxation, a Weatherhaven Series 4 shelter $(8.5 \times 4.3 \mathrm{~m})$ for engineering support, and a further Weatherhaven Series $4(14.6 \times 4.3 \mathrm{~m})$ to cover the drilling pit (Figure 4 gives an impression of the drilling camp). Rudimentary toilets and showers were provided using pyramid tents, while a small shelter was used to house the main camp generator. Only the Weatherhaven covering the drilling trench was left erected over the winter season when the site was unoccupied, and it suffered some structural damage due to burial by snowdrift.

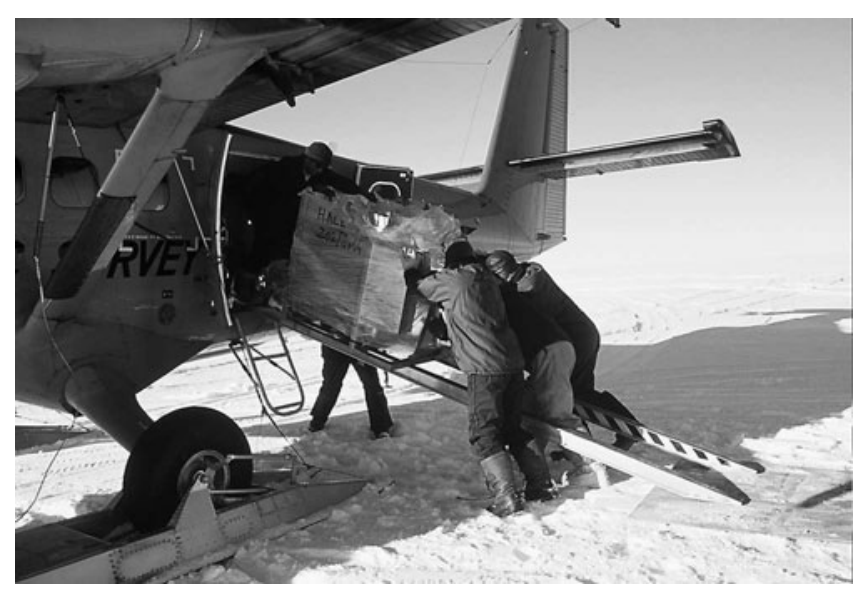

Fig. 6. Unloading the winch frame from the Twin Otter using $\mathrm{H}$-section ramps.

\section{THE BERKNER ISLAND DRILLING SYSTEM DESIGN}

Drawing on the experience gained from the EPICA drilling project (Augustin and Antonelli, 2002), a new drilling system was designed by the Laboratoire de Glaciologie et Géophysique de l'Environnement (LGGE) with BAS and the Institut National des Sciences de I'Univers (INSU, France) Technical Division in order to fit the specific constraints of the Twin Otter transport route. The main constraints on the design were maximum load carried by Twin Otter (up to around $900 \mathrm{~kg}$, depending on fuel load and operational factors), overall dimensions of the cargo door $(1.42 \mathrm{~m}$ high $x$ $1.27 \mathrm{~m}$ wide) and the length/width restrictions of loading a Twin Otter (Fig. 5). As an example, the latter constraint dictated the largest possible outer barrel tube length of $5.4 \mathrm{~m}$, which ultimately restricted the maximum core length possible to $2.05 \mathrm{~m}$. As another example, the restriction on the size of the cargo door governed the choice of main generator, and ultimately the maximum motor power, and therefore the speed and maximum pull of the drilling winch. A secondary consideration in the design of the system was handling in the field: although heavy lifting equipment was available on the stations to load the aircraft, once at the drilling site no lifting equipment was available, and all equipment needed to be capable of being handled over snow, by the use of manpower, or skidoo and sledge. BAS operations use two lightweight $\mathrm{H}$-beam ramps to assist in loading and unloading heavy equipment in the field. Figure 6 shows an example of aircraft cargo handling.

\section{The winch and mast}

The winch-system (Fig. 7) detailed design and manufacture was subcontracted to the Danish company MacArtney A/S. It was designed and built specifically for this project in collaboration with LGGE and BAS in order to fit into a Twin Otter and to meet the technical specification for drilling in ice. The motor, the gear-reducer and the mast and mast tilt mechanism could easily be dismounted from the main frame to help manhandling in the field. The winch frame is made of square stainless-steel profile $(50 \times 50 \times 5 \mathrm{~mm})$. Its overall dimensions are $1200 \mathrm{~mm}$ long, $1100 \mathrm{~mm}$ wide and $1080 \mathrm{~mm}$ high. The Lebus drum capacity is $1100 \mathrm{~m}$ of $8.4 \mathrm{~mm}$ diameter cable in 19 layers; a level-wind system managed the cable feed onto the drum. The winch is powered by a VEM $9 \mathrm{~kW}$ $(3 \times 400 \mathrm{~V}, 50 \mathrm{~Hz})$ electric motor with a Wistro K21R cooler, 


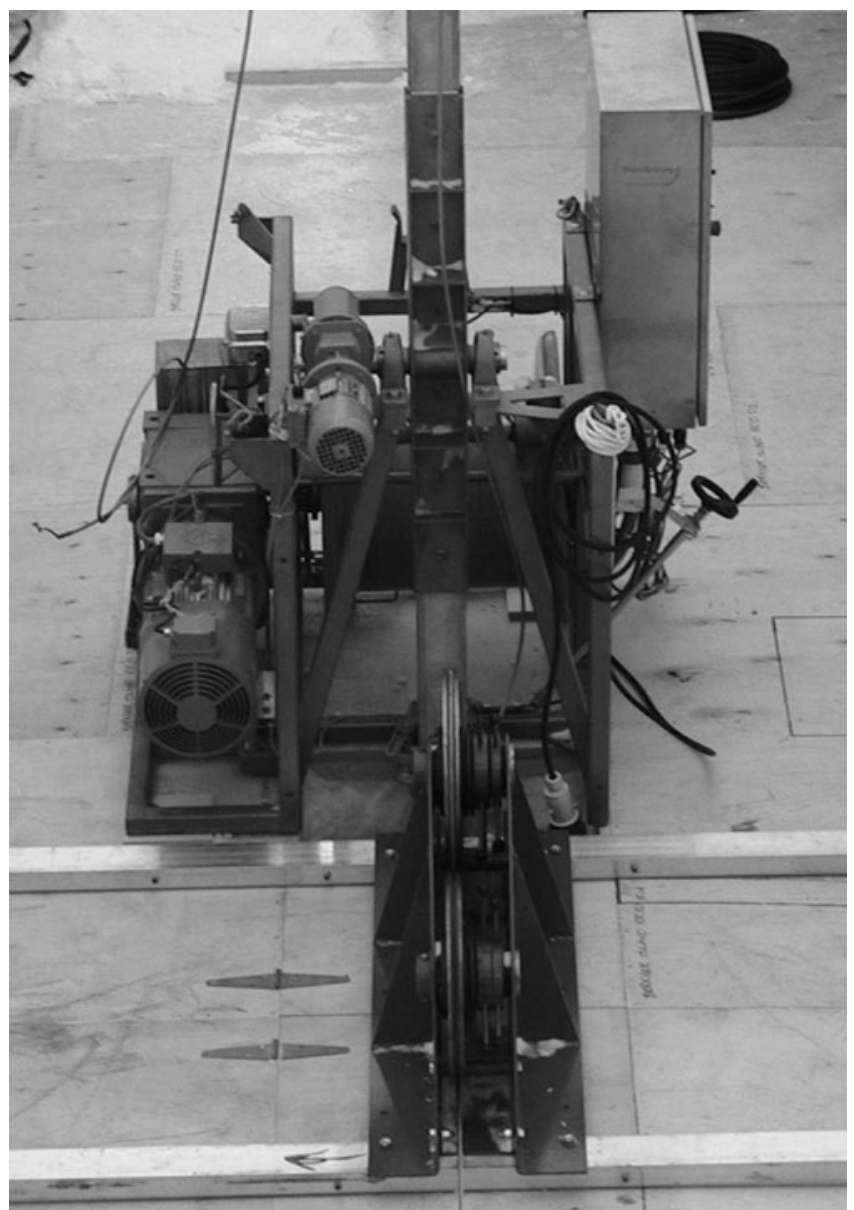

Fig. 7. The winch and mast system with cable-tensioning device in the foreground, ready to roll cable onto Lebus drum, visible at the rear of the frame. On the left of the winch frame is the motor and gear reducer; on the right is the handle for engaging the locking mechanism for the mast in the upright position and the winch control panel; in the top centre of the frame is the mast tilt mechanism with its gear motor.

driving through a Tramec TC $160 \mathrm{C}$ gear reducer (reduction ratio $I=80: 1)$. The gearbox includes the facility to attach a handle for manual winding to recover the drill in the event of an electrical systems failure. The motor is driven by an Omron 3G3MV-A frequency inverter associated with an absolute encoder set up on the winch motor. This system allowed a cable winding speed ranging from 0.3 to $43 \mathrm{~m} \mathrm{~min}^{-1}$, and a maximum pull of $15 \mathrm{kN}$ on the first cable layer, reducing to $10.5 \mathrm{kN}$ on the top layer. A Mayr $104 \mathrm{~V}$ electric parking brake on the winch motor linked to the motor drive prevented cable run-out, and could be disengaged for drilling. To slow the winch speed during drill descent, the motor can be switched to a generator mode, and the power dumped across a resistive load. A stainless-steel mast of welded box-section construction, $100 \mathrm{~mm}$ square and of overall length $7.4 \mathrm{~m}$, split in the middle for transport, was mounted on an axis at the upper front of the frame, and topped with a nylon sheave wheel $0.45 \mathrm{~m}$ in diameter. The mast could be tilted from the vertical to the horizontal for unloading the core and chippings either manually or via an electric motor-driven tilting system. Once in the vertical drilling position, it was clamped using manually closed claws, with a safety cut-out to prevent winching with the mast unsecured. The winch system weighed $850 \mathrm{~kg}$ overall

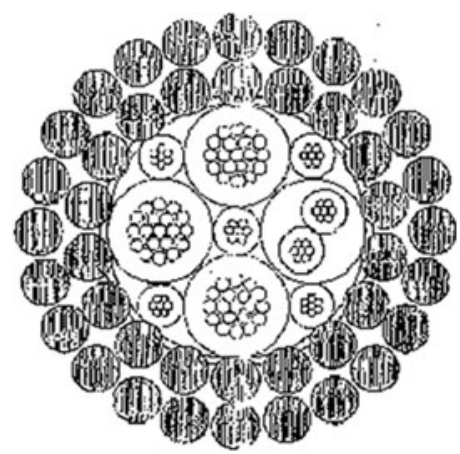

Fig. 8. Cross-section of the drill cable.

(without cable), and this could be broken down into components that could be transported and assembled in the field without machinery: winch frame $420 \mathrm{~kg}$, motor $85 \mathrm{~kg}$, gear reducer $150 \mathrm{~kg}$, mast system $100 \mathrm{~kg}$, pivoting axis system $65 \mathrm{~kg}$ and control box $30 \mathrm{~kg}$.

\section{The cable}

The cable is manufactured by Schlumberger. It comprises eight conductors plus a twisted pair (for a total of ten conductors) in an armoured outer cable with an overall diameter of $8.4 \mathrm{~mm}$ (Fig. 8). The armour wires are high-tensile, galvanized improved plough steel. The breaking strength of this cable is $38.8 \mathrm{kN}$ while the elastic limit is estimated around $25 \mathrm{kN}$. Cable weight was $280 \mathrm{~kg} \mathrm{~km}^{-1}$, and approximately $1100 \mathrm{~m}$ of cable was loaded onto the winch (totalling $308 \mathrm{~kg}$ ). The larger-diameter conductors were used to transmit power to the drill motor; each had a resistance of $21 \Omega \mathrm{km}^{-1}$, while the smaller-diameter conductors were used for transmission of analogue sensor signals from the drill pressure tube.

\section{THE DRILL}

LGGE built a new drill modified to the logistic constraints of the Berkner project (particularly a shortened barrel, with limited electronics). The lower part of the drill draws heavily on the designs of the EPICA drill, and the earlier Hans Tausen drill (Johnsen and others, 2007), with a motor driving the rotation of a hollow shaft, a volumetric pump and a core barrel inside a fixed outer tube; the drill head was fixed on the inner rotating core barrel. A series of 24 grooves were machined on the inside of the outer tube, and three aluminium spirals were mounted on the core barrel in order to improve the chips/drilling-fluid transportation from the bottom of the drill to the chip chamber. The dimensions of the sections of the drill are given in Table 2. The pump used in this Berkner drill is the 'double piston pump' designed in Copenhagen University for the EPICA drill (personal communication from N. Gundestrup, S.J Johnsen and S.B. Hansen, 2000). Most mechanical components of this drill are made in stainless steel $(304 \mathrm{~L}$ and $316 \mathrm{~L})$, while the antitorque skates are spring steel, and the pump body brass.

The motor/gear section incorporates a $190 \mathrm{~V}$ permanent magnet d.c. motor (TEM MP66 KL $190 \mathrm{~V} 2000 \mathrm{~T}$, with a gear reduction of $24: 1)$ producing $600 \mathrm{~W}$ for a duration of $15 \mathrm{~min}$ at $2000 \mathrm{rpm}$, with a continuous stall torque of $2.1 \mathrm{Nm}$ (peak stall torque $10 \mathrm{Nm}$ ). The reduction ratio gave a drill-head rotation speed of 10-80 rpm. The electrical loss on the cable line is typically close to $50 \mathrm{~V}$, the motor being 
Table 2. Berkner Island electromechanical drill characteristics. OD: outer diameter; ID: inner diameter

\begin{tabular}{lc} 
Drill head \\
CUTTERS \\
Number \\
OD \\
ID & 3 \\
Face angle & $129.6 \mathrm{~mm}$ \\
Clearance angle & $98.0 \mathrm{~mm}$ \\
CORE DOGS & $45^{\circ}$ \\
Number & $12^{\circ}$ \\
OD on core dogs & \\
BODY & 3 \\
OD & $125 \mathrm{~mm}$ \\
ID & \\
\hline
\end{tabular}

\begin{tabular}{lc} 
Outer core barrel & \\
OD & $118 \mathrm{~mm}$ \\
ID & $113 \mathrm{~mm}$ \\
Overall length & $5.4 \mathrm{~m}$ \\
\hline
\end{tabular}

$\begin{array}{lc}\text { Inner core barrel } & \\ \text { OD } & 104 \mathrm{~mm} \\ \text { ID } & 100 \mathrm{~mm} \\ \text { Length } & 2.138 \mathrm{~m} \\ \text { Rotation speed } & 40-80 \mathrm{rpm}\end{array}$

\begin{tabular}{ll}
\hline Hollow shaft & \\
OD & $30 \mathrm{~mm}$ \\
ID & $20 \mathrm{~mm}$ \\
Length & $3.2 \mathrm{~m}$ \\
\hline
\end{tabular}

$\begin{aligned} & \text { Pump } \\ & \text { Type } \\ & \text { Stroke length }\end{aligned}$

$\begin{array}{lc}\text { Chip chamber } & \\ \text { OD } & 114.3 \mathrm{~mm} \\ \text { ID } & 110.3 \mathrm{~mm} \\ \text { Length } & 3.213 \mathrm{~m}\end{array}$

$\begin{array}{lc}\text { Pressure tube } & \\ \text { OD } & 114.3 \mathrm{~mm} \\ \text { ID } & 98 \mathrm{~mm} \\ \text { Length } & 0.8 \mathrm{~m} \\ \text { Pressure tight } & 30 \mathrm{MPa}\end{array}$

\begin{tabular}{lc}
\hline Motor & \\
Type & TEM MP66 KL (DC, permanent magnet) \\
Voltage & $190 \mathrm{~V}$ \\
Power & $600 \mathrm{~W}$ \\
Rotation speed & $2000 \mathrm{rpm}$ \\
Moment & $2.1 \mathrm{Nm}$
\end{tabular}

Gear-reducer

Ratio

$1: 24$

$\begin{array}{lc}\text { Anti-torque section } & \\ \text { Type } & 3 \text { leaf springs, ISTUK type } \\ \text { Length } & 960 \mathrm{~mm}\end{array}$

Overall length $\quad 7.2 \mathrm{~m}$

Overall weight $160 \mathrm{~kg}$

driven at around 110-120 V (160 V at surface) with a current starting of $1 \mathrm{~A}$ at the beginning of a run, reaching $2.5 \mathrm{~A}$ at the end of a run. To enable a simpler operation in the field, there is no 'electronics section' in the pressure tube of this drill, such as found in the EPICA drill. There is only analogue signal transmission between the drill and surface (limited to detection of anti-torque rotation, load on the drill head and tachymeter) with the $8+2$ conductors plus armour cable contacts passed through a 12-channel slip ring (Focal, type 180/12) in the Lebus drum axle.

The anti-torque section uses spring-steel flat skates, in common with most deep ice-core drills (Gundestrup and others, 1984). The link between the drill and the cable was made by potting the splayed cable in a low-meltingtemperature expansive metal alloy (trade name Cerromatrix).

\section{Drilling-fluid system}

In common with other recent European ice-core drilling operations, the Berkner project used a mixture of ExxonMobil 'Exxsol' dearomatized hydrocarbon solvent and HCFC$141 \mathrm{~b}$ to achieve a fluid of the optimum density, and other physical characteristics (Talalay and Gundestrup, 2002). For this project, Exxsol D-60 was chosen as the base drilling fluid, with a density of $0.790 \mathrm{Mg} \mathrm{m}^{-3}$ at $15^{\circ} \mathrm{C}$, and $75 \times$ $205 \mathrm{~L}$ drums $(15375 \mathrm{~L})$ were delivered to the drill site. The densifier used was HCFC-141b, with the trade name Solkane and density $1.240 \mathrm{Mg} \mathrm{m}^{-3}$ at $25^{\circ} \mathrm{C}$, and $4096 \mathrm{~L}(5080 \mathrm{~kg}$ fluid) of densifier were delivered to the site in drums. Mixing of the fluid was carried out in an open $205 \mathrm{~L}$ drum, optimizing the density for achieving a slight over-pressure in the borehole with a fluid column height maintained at $80-100 \mathrm{~m}$ from the surface (the casing reached $67 \mathrm{~m}$ from the surface, and the pore close-off depth was $64 \mathrm{~m}$ ). Fluid was made in batches of $\sim 180 \mathrm{~L}$, using the actual fluid temperature as delivered from the surface-stored drums and a pre-calculated chart to specify the density required at the surface to achieve the correct in situ density in the borehole (which varied in temperature from around $-26^{\circ} \mathrm{C}$ near the surface, to $-11^{\circ} \mathrm{C}$ at the base), and mixed using an electric paint-stirrer and narrow-range glass bulb hydrometers. Generally, the density of the mixture at the surface was about $946 \mathrm{Mg} \mathrm{m}^{-3}$, at an ambient temperature of around $-12^{\circ} \mathrm{C}$, with a mass concentration of densifier, on average, of $27 \%$. Between deep-drilling seasons, the fluid level was left at about $80 \mathrm{~m}$, and no change in the fluid level between seasons was observed. By the end of the drilling, 20 drums of D-60 remained of the original number, but all drums of Solkane had been consumed, implying a total volume of $15370 \mathrm{~L}$ of mixed fluid had been consumed. The theoretical column volume (from $80 \mathrm{~m}$ to $948 \mathrm{~m}$, at diameter $129.6 \mathrm{~mm}$ ) is $11450 \mathrm{~L}$, implying wastage of $25 \%$. This seemed a rather high value; for example, in the 2000/01 EPICA drilling season, the wastage was $17.5 \%$ (Augustin and Antonelli, 2002). Although there was no loss from the borehole between seasons when the fluid column was left below the level of the casing, and we did not fill the borehole during drilling above the lowest level of the casing, there may have been some loss into the firn during raising of the drill, and also when adding further fluid to the borehole from a hose at the well-head, because the fibreglass casing sections were only slipped together and not bonded. All drilling chippings were collected and the fluid recovered using a Henri Petit-Jean ECO500 centrifuge and returned to the borehole. Some fluid was lost from the cable once 
rewound onto the drum; we attempted to catch this on a shallow plastic tray, but inevitably some was lost. Between runs, the hollow shaft was washed down with drilling fluid over an aluminium channel tray draining into open plastic boxes, and this fluid was also recovered by centrifuge and reused, though some was lost in spray.

\section{Generators}

The electrical supply for the drilling pit (including the winch, drill, centrifuge, fume extraction fans and ice-core processing line) was supplied by a single three-phase $400 \mathrm{~V} 50 \mathrm{~Hz}$ (plus single phase $240 \mathrm{~V}, 50 \mathrm{~Hz}$ ) $16 \mathrm{kVA}$ model TN16K generating set supplied by SDMO. The electrical generator was driven by a $19.6 \mathrm{~kW}$ three-cylinder liquid-cooled diesel engine running at $3000 \mathrm{rpm}$, and the complete unit weighed $335 \mathrm{~kg}$. The fuel supplied to the generator was Avtur aviation fuel, with the addition of two-stroke oil at a 50:1 ratio. In general, the generator consumed around $55 \mathrm{~L}$ of fuel per day, operating for about 17 hours $\mathrm{d}^{-1}$. The remainder of the camp supply for leisure, messing and personal use was supplied by a range of small Honda petrol generators (single-phase $240 \mathrm{~V}$ a.c., $50 \mathrm{~Hz}$ and ranging from 0.75 to $4 \mathrm{kVA}$ ).

\section{PROGRESS OF THE DRILLING OPERATION}

In all, the drilling operation from initial input of fuel to the chosen drill site (south dome, Thyssenhöhe; see Table 1 for position) to the final uplift of all equipment from the field occupied six austral field seasons. Fuel for the drilling, plus for refuelling the aircraft, as well as the bulk of the drilling fluid was pre-deployed to the site before the build-up of the drilling infrastructure and equipment. Given the volume and weight of the fuel and fluid, this was shipped to a location just to the northeast of Berkner Island in the 1999/2000 season by the BAS ship RRS Bransfield, then transferred to the ice shelf by helicopters operating from the UK naval vessel HMS Endurance, before being flown to the drill site by BAS Twin Otters. In total, 270 drums of aviation fuel, a further 20 drums of petrol and 80 drums of D-60, together with 100 ice-core boxes, were pre-deployed to the drill site before the first scheduled drilling season. Further drums of aviation fuel and the Solkane were flown in during later seasons to utilize the inbound leg of ice-core and equipment uplift flights.

The first drilling season was scheduled for 2001/02, when the planned work included the establishment of the drilling infrastructure, and the pilot borehole and casing. However, due to unusual ice conditions in the Weddell Sea, the BAS supply ship bound for Halley, carrying all the drilling cargo and part of the field team, became fast in the ice and was ultimately unable to reach and relieve Halley that season. None of the party (some of whom remained on the ship for almost 4 months) was able to reach Berkner Island.

The planned work was rescheduled for 2002/03, and this time met more success. With six people in the field, three were able to drill and sample one $80 \mathrm{~m}$ borehole for firn air (as a part of the European Union-funded CRYOSTAT project to sample firn air at several sites), while the other three were able to excavate a drilling trench $14 \mathrm{~m}$ long $\times 4 \mathrm{~m}$ wide $\times 4 \mathrm{~m}$ deep, using a combination of a small snow-blower, a chainsaw, spades and a sledge. The trench was covered by a Weatherhaven series 4 shelter, $14.6 \times 4.3 \mathrm{~m}$ in size, though not before the mostly excavated trench was filled in by snowdrift during a storm. Once fully excavated, the floor was levelled, and covered by $25 \mathrm{~mm}$ plywood sheets on

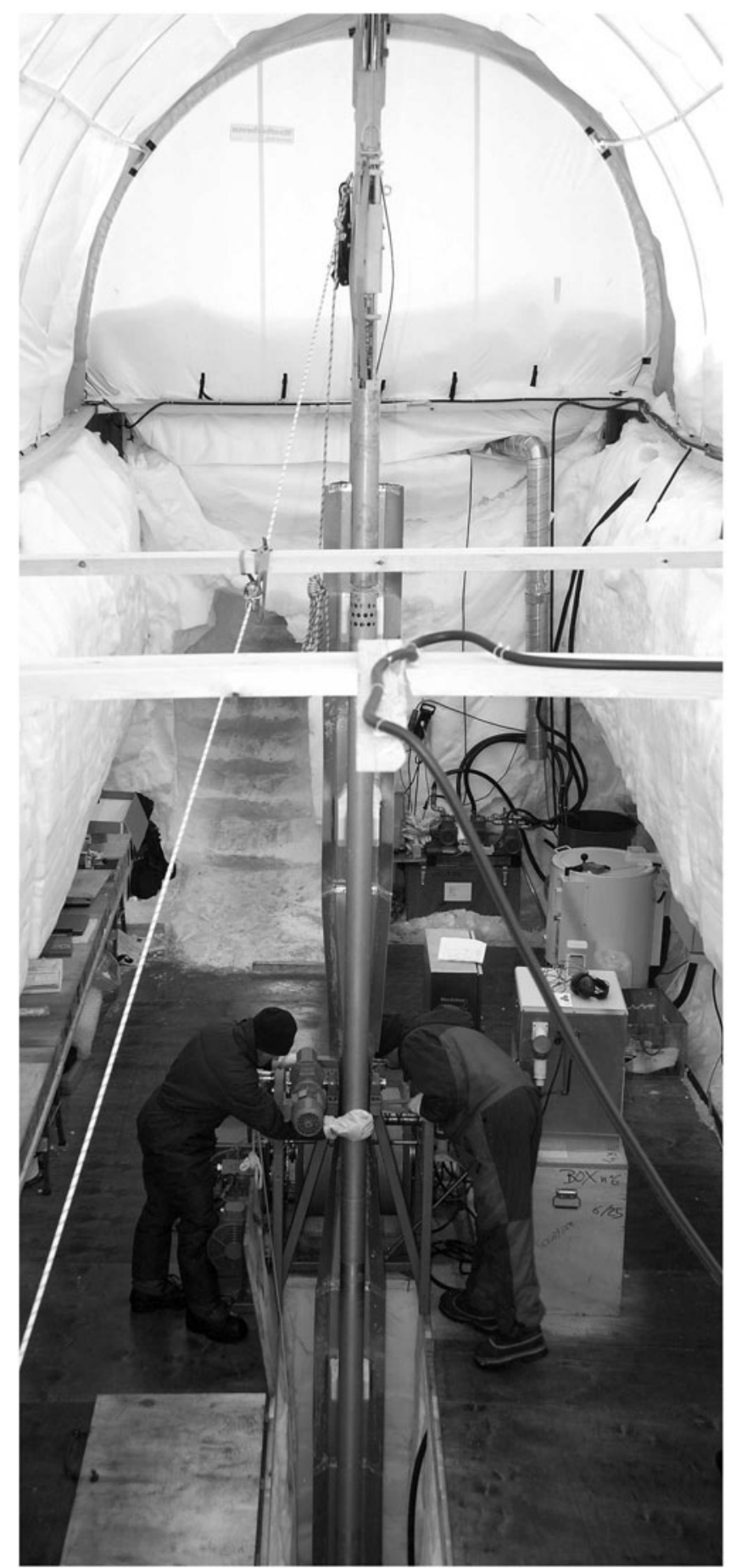

Fig. 9. The covered drilling pit, with deep ice-core drill system.

$210 \times 70 \mathrm{~mm}$ wooden beams. In the centre of the trench, a further $4 \mathrm{~m}$ deep inclined trench was excavated to accommodate the tilting mast, covered by hatches in the wooden floor. A $70 \mathrm{~m}$ deep pilot borehole was drilled from the bottom of the hollow shaft using a shallow ice-core drill (Mulvaney and others, 2002a) mounted on the wooden floor above the trench. This pilot hole was enlarged by reaming to a final diameter of $222 \mathrm{~mm}$ by mounting three successively larger reamers of diameters 135, 183 and $222 \mathrm{~mm}$ (loaned to us by S.B. Hansen of the Niels Bohr Institute, Copenhagen, Denmark) onto the shallow-drill motor/anti-torque sections. The lowest few metres of the borehole was thus stepped down from $222 \mathrm{~mm}$ to the drill diameter, similar to that 


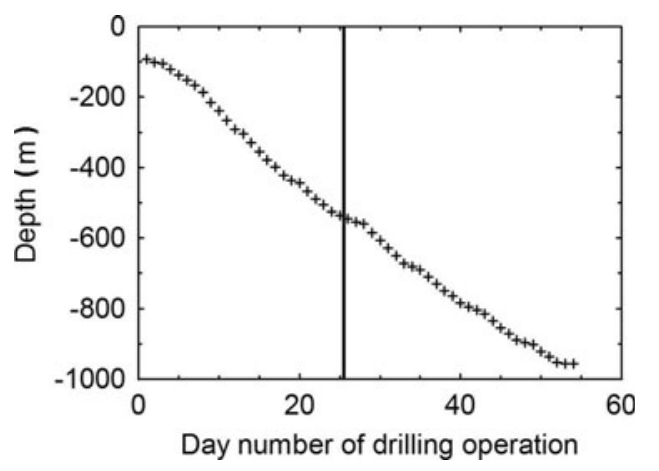

Fig. 10. Progress of the drilling: a vertical line marks the boundary between the two deep drilling seasons.

shown in the figure in Johnsen and others (1994). A lightweight fibre-reinforced plastic casing $(200 \mathrm{~mm}$ internal diameter, $3 \mathrm{~mm}$ wall thickness and $216 \mathrm{~mm}$ outside diameter at the joint, $2.5 \mathrm{~kg} \mathrm{~m}^{-1}$ ) in $3 \mathrm{~m}$ long sections was lowered down the borehole on three $1.5 \mathrm{~mm}$ diameter stainless-steel wires using small manual winches to $67 \mathrm{~m}$ depth. The sections were not bonded as planned, due to our inability to bond them in the field sufficiently straight to fit the narrow tolerance of the reamed hole. Once the casing was in place, the pilot borehole was extended to $86 \mathrm{~m}$.

In 2003/04, the main ice-core drilling winch system was installed in the drill trench, and the cable loaded onto the drum using a cable tensioner to apply a load of around $300 \mathrm{~kg}$ when enrolling. Drilling using the new deep ice-core drill commenced after loading the borehole with the drilling fluid. Some minor problems were encountered, but in general the system performed well and as designed. The setting up of the system, together with some logistic problems, limited the drilling to a total of 25 drilling days during the season. Drilling operations (Fig. 9) lasted for 16 hours d $^{-1}$ (8 hours on Saturday), in shifts of 4 hours with four people per shift, and reached $526 \mathrm{~m}$ depth.

The following season, 2004/05, had further delays, when the drilling team were delayed getting to Rothera for 3 weeks due to bad weather. A further 29 days of drilling, again with few problems, saw the drilling extend from $526 \mathrm{~m}$ to the final encounter with the bed on 14 January 2005 at 948 m depth.

The total drilling period using the deep drilling system was 54 days; the progress is shown in Figure 10. The mean production rate was $112 \mathrm{mweek}^{-1}$ (including training periods at the start of each season) and the overall mean

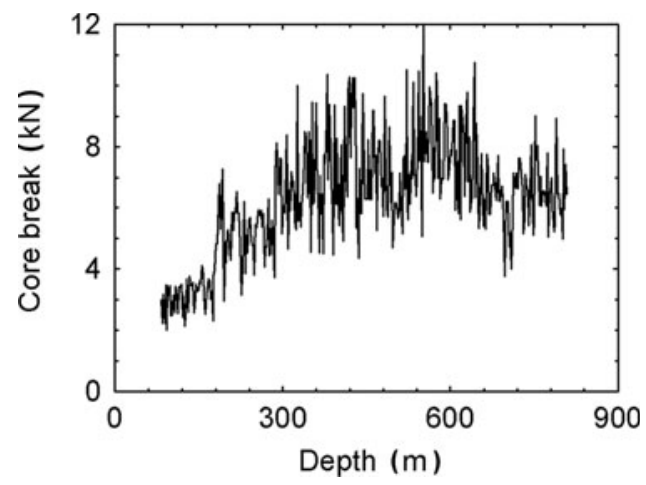

Fig. 11. Force used to break core at the end of each drilling run, expressed in $\mathrm{kN}$.

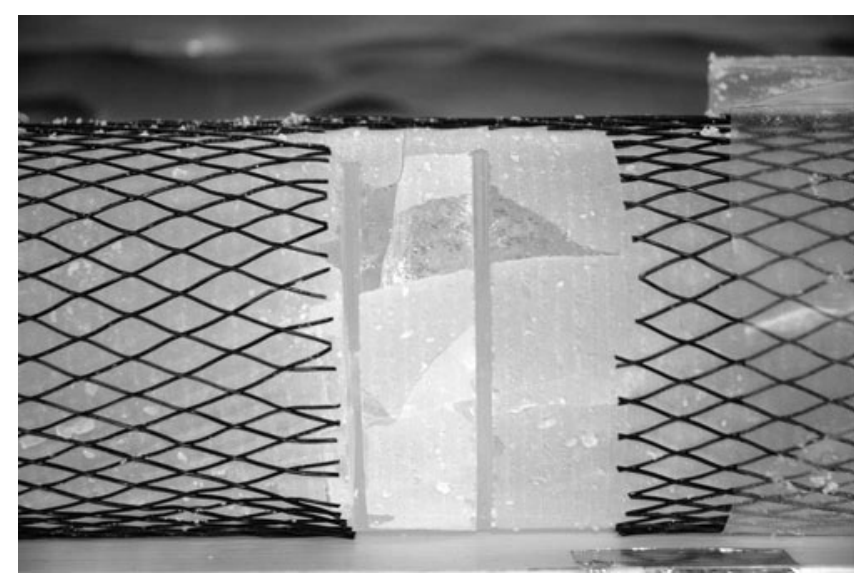

Fig. 12. Elastic netting used to contain brittle ice: this core from $920 \mathrm{~m}$ has been partially cut with the circular saw shortly after drilling in order to take a subsample, and shows the limited extent of damage to the 'brittle ice'.

core length was $1.89 \mathrm{~m}$. The core breaks (after making a correction for the cable weight in the fluid) increased steadily up to around $8 \mathrm{kN}$ at the $400 \mathrm{~m}$ depth (Fig. 11), before stabilizing between 6 and $10 \mathrm{kN}$. The core breaks decreased slightly after $650 \mathrm{~m}$, corresponding to the entry into glacial ice.

Little processing of the ice was carried out in the field. A hand-held electrical conductivity meter was used to measure d.c. conductivity in the upper $450 \mathrm{~m}$. At around this depth, the ice became increasingly brittle, and remained brittle to within a few metres of the bed. The cores were cut into $550 \mathrm{~mm}$ sections for bagging and packing in insulated boxes for transport using either a bandsaw or, more successfully in the brittle ice, a circular cut-off saw with tungsten carbide tipped blades. One innovation in the brittle ice was to push the brittle ice directly from the core barrel into an elastic plastic mesh tube to ensure that if any breakage did occur in handling, the core fragments were contained (Fig. 12). In fact, although 'brittle', the ice was never sufficiently damaged to impact a continuous stratigraphy. A rudimentary core buffer was maintained in the drill trench, and in general the cores were processed a few days after recovery. All cores were retrograded by Twin Otter and shipped in a reefer container in the same season as drilling.

The final few metres to the bed showed little in the way of visible sediment. However, the final $0.5 \mathrm{~m}$ of ice recovered showed a rapid change from clear ice to sediment-laden ice (Fig. 13). The transition from ice to sediment was abrupt: once the final ice core had been recovered, all subsequent runs of the drill captured no further ice, but instead large quantities of fine sand were covering the barrel and fluid pump. Several further attempts were made to penetrate the bed, but with no success beyond approximately $5 \mathrm{~cm}$ and at a cost of several severely worn and abraded cutters. The drilling was consequently terminated.

In 2005/06, the drill site was reoccupied and the winch system set up over the capped borehole. Using a modified Polar Ice Coring Office (PICO) manual drill barrel equipped with tungsten carbide tipped cutters mounted on a standard electromechanical drill motor and anti-torque system, we penetrated a further $50 \mathrm{~cm}$ into the sediment. Unfortunately, we were unable to capture a sediment core, but did succeed in recovering several $\mathrm{kg}$ of the basal material on the barrel 


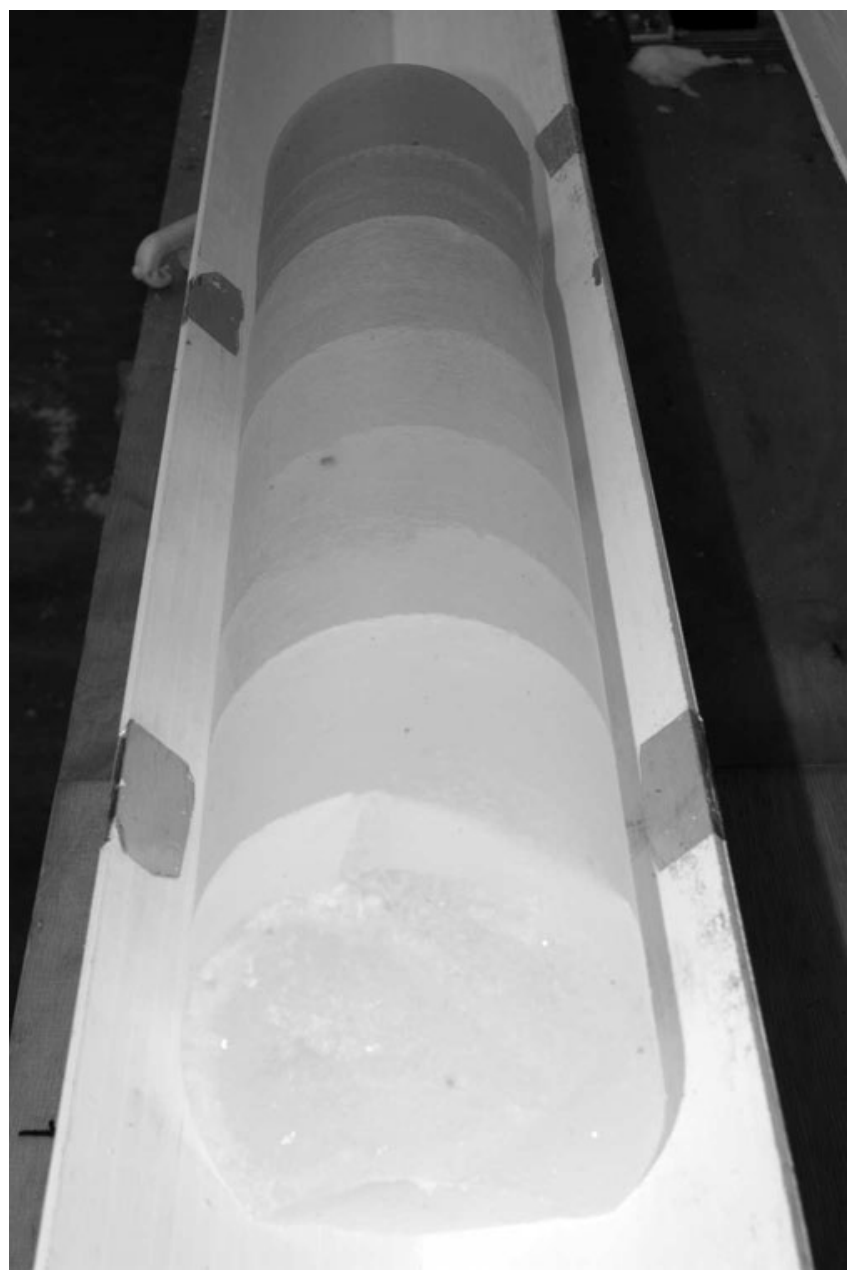

Fig. 13. The final $0.5 \mathrm{~m}$ of ice core before the basal sediment was encountered; the deepest ice is furthest from the camera. The banding is due to horizontal cracks in the core from the drilling which were not apparent on earlier cores. Below this section, no further ice was recovered, with only fine sand sediment recovered from subsequent drilling runs. Note the occasional larger conglomerate particles in the ice.

spirals, which appeared to be comprised of fine unconsolidated quartz sand. There were few 'ice chips' recovered in the barrel with the sand, suggesting we were drilling in sediment rather than ice with inclusions.

\section{FINAL COMMENTS}

This 'lightweight' ice-core drilling project, staffed by a maximum of eight people at the drill site, successfully recovered an ice core to $948 \mathrm{~m}$ depth from a remote Antarctic site at almost $80^{\circ} \mathrm{S}$ in three short seasons, plus a fourth season for borehole measurements and basal sampling. Unusually, the sub-ice material was penetrated to a depth of $0.5 \mathrm{~m}$, and basal material recovered for analysis. The drilling approach to the bed was made easier by the relatively cold basal temperature, predicted by modelling to be in the range -10 to $-12^{\circ} \mathrm{C}$ and subsequently measured 1 year after drilling was completed as being $-11.6^{\circ} \mathrm{C}$ (personal communication from E. Lefebvre, 2006). Although the model predicted a conservative age at the base of $>30 \mathrm{ka}$, initial analysis of the stable-isotope composition of the core suggests that the bottom age is possibly $>120 \mathrm{ka}$ : the LGM-Holocene transition is $350-300 \mathrm{~m}$ above the bed.

\section{ACKNOWLEDGEMENTS}

This project was financed by the British Antarctic Survey and Natural Environment Research Council of the UK, and the Institut Polaire Français-Paul Emile Victor and Institut National des Sciences de I'Univers of France. The members of the field teams over the four seasons of the project contributed enormously to making the drilling successful: S. Bernard, G. Littot, T. McCormack, A. Bory, G. Teste, M. Calzas, S. Foord, E. Thomas, E. Lefebvre, J. Triest, D. Ellis, A. Berry, S. Herniman and T. O'Donovan. The authors particularly thank their colleagues in the field for making the whole project thoroughly enjoyable. They also express their sincere thanks to the Operations and Logistics teams of BAS for their support throughout, and to the members of Halley Station for their efforts in handling all the cargo and the ice cores during the project.

\section{REFERENCES}

Augustin, L. and A. Antonelli. 2002. The EPICA deep drilling program. Mem. Natl. Inst. Polar Res., 56, Special Issue, 226-244.

Blunier, T. and 9 others. 1997. Timing of the Antarctic cold reversal and the atmospheric $\mathrm{CO}_{2}$ increase with respect to the Younger Dryas event. Geophys. Res. Lett., 24(21), 2683-2686

Broecker, W.S. 1998. Paleocean circulation during the last deglaciation: a bipolar seesaw? Paleoceanography, 13(2), 119-121.

EPICA Community Members. 2006. One-to-one coupling of glacial climate variability in Greenland and Antarctica. Nature, 444(7116), 195-198.

Foldvik, A., T. Gammelsrød and T. Törresen. 1985. Circulation and water masses on the southern Weddell Sea shelf. In Jacobs, S.S., ed. Oceanology of the Antarctic continental shelf. Washington, DC, American Geophysical Union, 5-20. (Antarctic Research Series 43.)

Gundestrup, N.S., S.J. Johnsen, and N. Reeh. 1984. ISTUK: a deep ice core drill system. CRREL Spec. Rep. 84-34, 7-19.

Huybrechts, P. 2002. Sea-level changes at the LGM from icedynamic reconstructions of the Greenland and Antarctic ice sheets during the glacial cycles. Quat. Sci. Rev., 21(1-3), 203-231.

Jacobs, S.S. 2004. Bottom water production and its links with the thermohaline circulation. Antarct. Sci., 16(4), 427-437.

Johnsen, S.J., N.S. Gundestrup, S.B. Hansen, J. Schwander and H. Rufli. 1994. The new improved version of the ISTUK ice core drill. Mem. Natl. Inst. Polar Res., 49, Special Issue, 9-23.

Johnsen, S.J. and 16 others. 2007. The Hans Tausen drill: design, performance, further developments and some lessons learned. Ann. Glaciol., 47, 89-98.

Mulvaney, R. and 6 others. 2000. The transition from the last glacial period in inland and near-coastal Antarctica. Geophys. Res. Lett., 27(17), 2673-2676.

Mulvaney, R., S. Bremner, A. Tait and N. Audley. 2002a. A mediumdepth ice core drill. Mem. Natl. Inst. Polar Res., 56, Special Issue, 82-90.

Mulvaney, R. and 8 others. 2002b. 1000 year ice-core records from Berkner Island, Antarctica. Ann. Glaciol., 35, 45-51.

Ritz, C., V. Rommelaere and C. Dumas. 2001. Modeling the evolution of Antarctic ice sheet over the last 420,000 years: implications for altitude changes in the Vostok region. J. Geophys. Res., 106(D23), 31,943-31,964.

Rufli, H., B. Stauffer and H. Oeschger. 1976. Lightweight 50-meter core drill for firn and ice. In Splettstoesser, J.F., ed. Ice-core drilling. Lincoln, NB, University of Nebraska Press, 139-153.

Sandhäger, H. 1996. Review of the Münster airborne radio-echo sounding-data set: marine ice beneath Filchner-Schelfeis; bottom reflectivity and internal structures of Berkner Island. FRISP Rep. 9, 111-114. 
Schwander, J. and H. Rufli. 1988. Electromechanical drilling in dry holes to medium depths. In Rado, C. and D. Beaudoing, eds. Proceedings of the Third International Workshop on Ice Drilling Technology, 10-14 October 1988, Grenoble, France. Grenoble, Centre National de la Recherche Scientifique. Laboratoire de Glaciologie et Géophysique de l'Environnement.

Sowers, T. and M. Bender. 1995. Climate records covering the last deglaciation. Science, 269(5221), 210-214.

Steig, E.J. and 8 others. 1998. Synchronous climate changes in Antarctica and the North Atlantic. Science, 282(5386), 92-95.
Steinhage, D. and N. Blindow. 1996. First results of short pulse radio echo sounding on the top of Berkner Island. FRISP Rep. 9, 123-126.

Stocker, T.F. and S.J. Johnsen. 2003. A minimum thermodynamic model for the bipolar seesaw. Paleoceanography, 18(4), 1087. (10.1029/2003PA000920.)

Talalay, P.G. and N.S. Gundestrup. 2002. Hole fluids for deep ice core drilling. Mem. Natl. Inst. Polar Res., 56, Special Issue, 148-170.

Wagenbach, D. and 6 others. 1994. Reconnaissance of chemical and isotopic firn properties on top of Berkner Island, Antarctica. Ann. Glaciol., 20, 307-312. 